\title{
Article
}

https://doi.org/10.11646/phytotaxa.405.6.2

\section{The genus Aongstroemia in Latin America (Dicranaceae, Bryophyta) with special reference to Aongstroemia gayana}

\author{
GUILLERMO MARTÍN SUÁREZ*1,2 \& JUAN LARRAÍN ${ }^{3}$ \\ 'Unidad Ejecutora Lillo, CONICET - Fundación Miguel Lillo, Miguel Lillo 251, San Miguel de Tucumán (4000), Tucumán, Argentina. \\ ${ }^{2}$ Facultad de Ciencias Naturales e I.M.L., Universidad Nacional de Tucumán, Miguel Lillo 205, San Miguel de Tucumán, Tucumán, \\ Argentina.*suarezgm@csnat.unt.edu.ar \\ ${ }^{3}$ Instituto de Biología, Facultad de Ciencias, Pontificia Universidad Católica de Valparaíso, Campus Curauma, Av. Universidad 330, \\ Curauma, Valparaíso, Chile.
}

\begin{abstract}
The genus Aongstroemia is here reported as new for Argentina and Uruguay, based on collections of $A$. gayana, formerly considered a Chile endemic. The species is described and illustrated, and its distribution depicted in a map. We also report A. filiformis as new for the southern cone of South America, based on a single collection from Contulmo, Chile. We provide a key for the identification of the species of Aongstroemia of Latin America.
\end{abstract}

Keywords: Aongstroemia, Argentina, Bryophyta, Dicranaceae, Chile, Latin America, Uruguay

\section{Introduction}

Aongstroemia Bruch \& Schimp. (1846:171) is a small genus of acrocarpous mosses, characterized by julaceous, slender plants, with erect-appressed leaves whether dry or wet, a narrow costa, thick walled upper cells, and undifferentiated alar cells (Gradstein et al. 2001). The genus comprises seven currently accepted species, distributed in temperate areas of the Northern Hemisphere, South-East Asia, the Neotropics, southern South America, and southern Africa. The only boreal species are Aongstroemia longipes (Sommerf. 1826:52) Bruch \& Schimp. (1846:173), the type species of the genus, which has a wide distribution in temperate North America, Europe and Asia (Eckel 2007), and A. orientalis Mitt. (1891:154), widely distributed in temperate and tropical Asia, as well as in the Neotropics (Allen 1994). Three species are known from southern Africa: A. filiformis (P. Beauv. 1805:53) Wijk \& Margad. (1960:50), A. julacea (Hook. 1818:42) Mitt. (1869:27), and A. subcompressa Hampe ex Müll. Hal. (1859:215), the latter being a little known name probably conspecific with Dicranella subsubulata (Hampe ex Müll. Hal. 1858:162) A. Jaeger (1872:375). In Latin America the genus is represented by four species: the Afro-American $A$. filiformis, the Pantropical-Asian temperate $A$. julacea, the Asian-Neotropical A. orientalis, and the austral A. gayana (Mont. 1845:112) Müll. Hal. (1848:427), with a distribution until now considered endemic to central and south Chile (Müller 2009).

Some plants recently collected in Uruguay and a herbarium voucher from Argentina were identified as A. gayana. The genus and species have not been previously recorded from Argentina or Uruguay (Matteri 2003, 2004). We provide a description and the first illustrations for this species, after the first and only illustration available for the species (Gay 1850). We also found a herbarium specimen corresponding to A. filiformis from south-central Chile. A key for the identification of the Latin American species of the genus is presented.

\section{Materials \& Methods}

As part of the project "Studies on Bryophytes in the Southern Cone (Systematics and Phylogeny)", we studied types and other specimens from CONC, DRE, JE, LIL, LIL-Matteri, LPS, MO and PC, in addition to our own collections deposited in CONC, CTES and LIL. The specimens were studied morphologically with traditional techniques for bryophytes and mounted in water-glycerine-phenol or Hoyer's solution (Anderson 1954). 


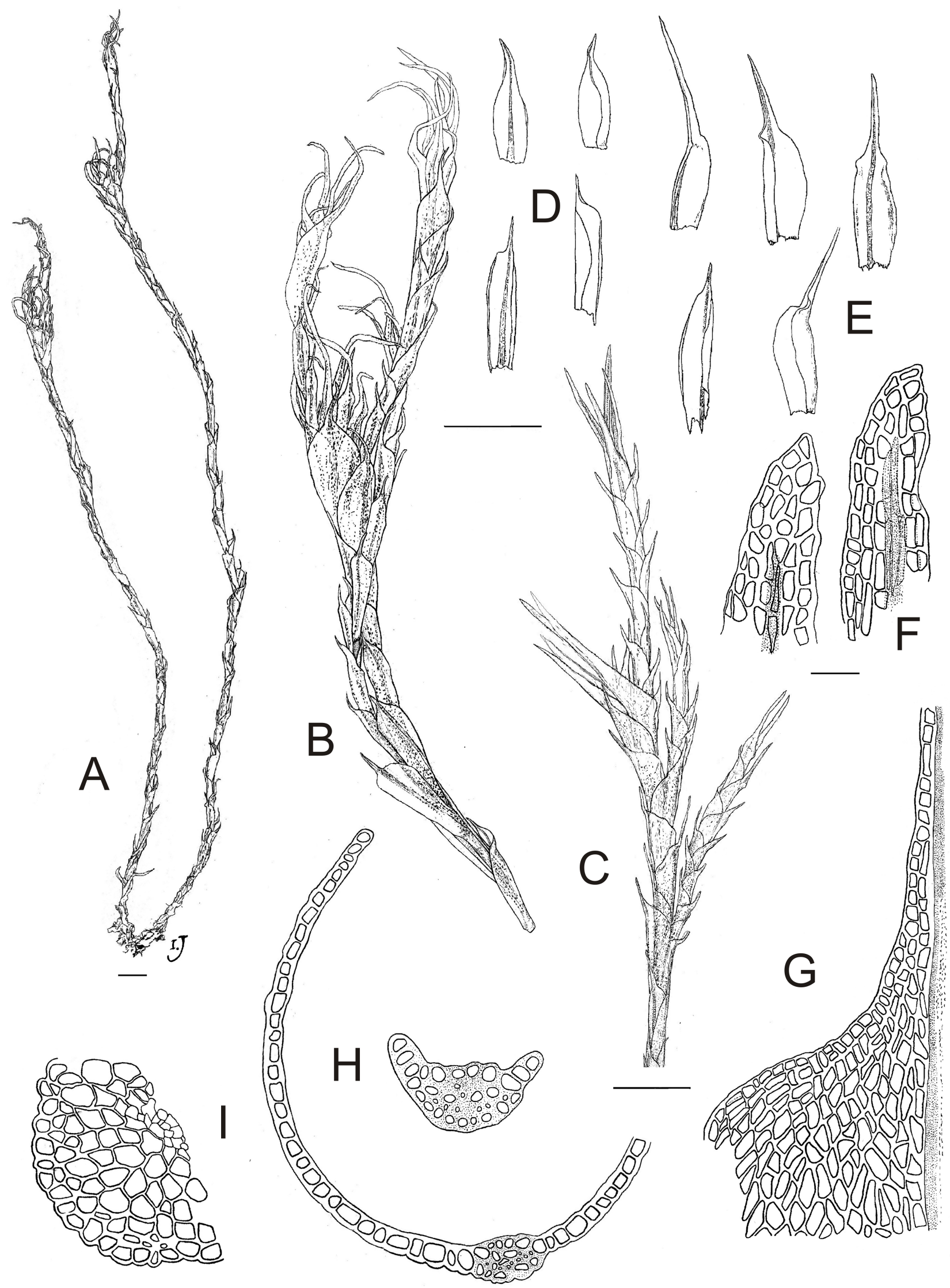

FIGURE 1. Aongstroemia gayana. A, Dry plants; B, C, Wet plant; D, Leaves; E, Perichaetial leaves; F, Leaf apìces; G, Shoulder cells; H, Transverse sections of the leaf; I, Stem cross section. A, B, C, D, E= 1mm. F, G, H, I= $25 \mu \mathrm{m}$. 


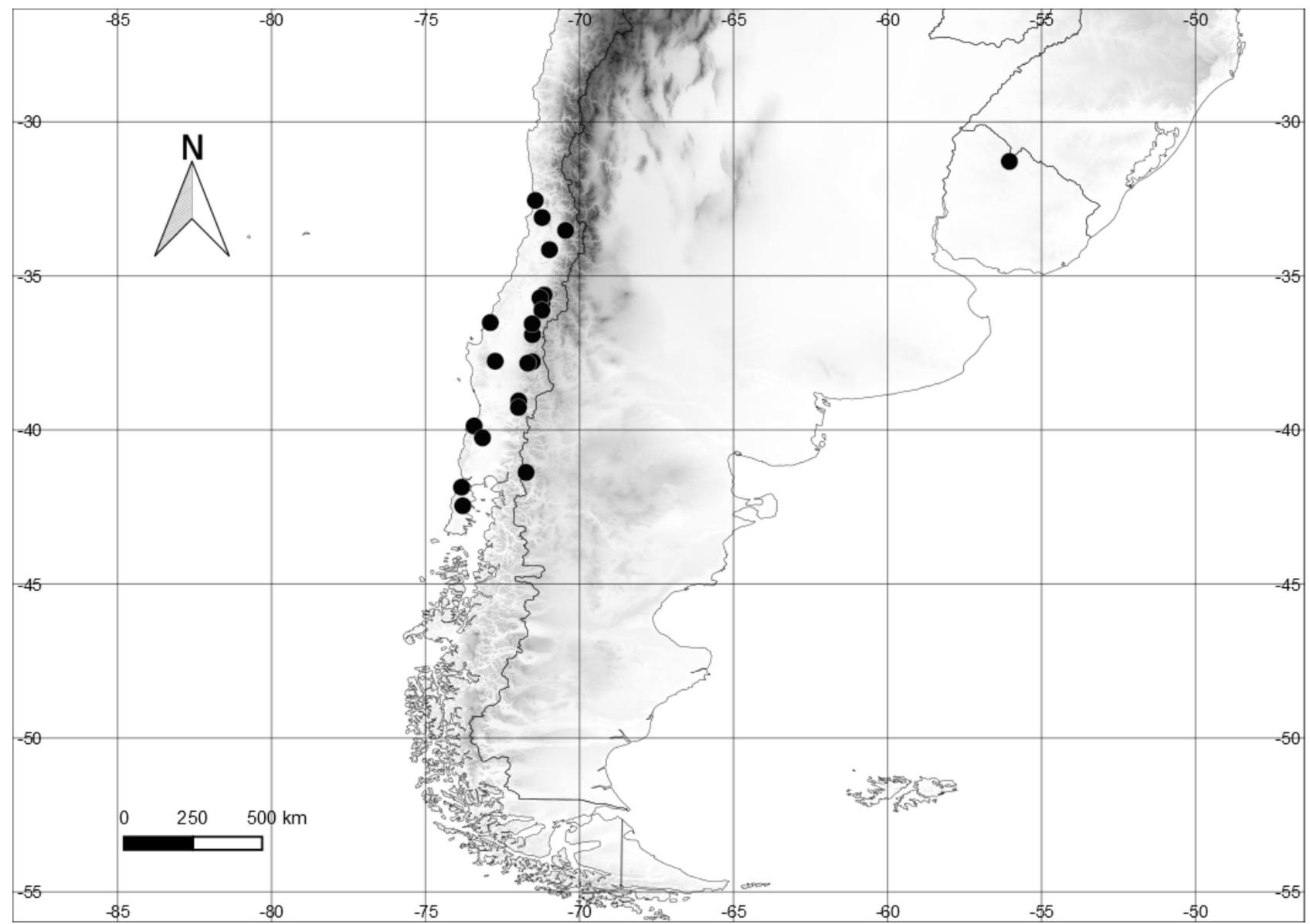

FIGURE 2. Aongstroemia gayana. Distribution map.

\section{Results}

\section{Taxonomic Treatment}

Aongstroemia gayana (Mont.) Müll. Hal., Syn. Musc. Frond. 1: 427. 1848. Dicranum gayanum Mont., Ann. Sci. Nat., Bot., sér. 3, 4: 112. 1845. Type citation: Hab. in Chile australiori ad terram species frequens à cl. C. Gay inventa et cujus nomine par erat illam insignire. Lectotype (designated here): Chili austral, C. Gay (PC 146666!). Isotype: LILMatteri! [Fig. 1]

Plants small to medium size, slender, forming loose tufts, green to yellowish-green, blackish below. Sterile and young plants filiform, with leaves becoming long subulate in distal portions of mature plants. Stem 15-40 mm long, erect and slender, green to reddish, terete foliate, simple or few branched near the tip by subfloral innovations; transverse section rounded to oval, ca. $100 \mu \mathrm{m}$ in diameter, central strand present, well developed, formed by a group of collapsed cells, sclerodermis present, formed by smaller and thick walled cells, hyalodermis not differentiated; axillary hairs up to $350 \mu \mathrm{m}$ long, formed by 3-5 hyaline and elongated cells. Leaves imbricate, clasping the stem and clearly tubulate, with basal lamina wings overlapping each other in clasping base, wide oblong-ovate to obovate at base, 2.0-3.0 mm long, $1.0-1.2 \mathrm{~mm}$ wide at clasping base, abruptly narrowed into a blunt point (seldom lacking and then leaf apex obtuse), often dark-colored, the distal leaves sometimes long subulate, with subula reaching the same length of the clasping base, subulae adpressed to stems; margins plane, entire proximally, in subulate leaves also entire or with scattered blunt teeth in the distal part of subula; costa weak to strong, percurrent or excurrent in distal subulate stem leaves; nerve in cross section (40-)60-100 $\mu \mathrm{m}$ wide, with a row of ventral and dorsal enlarged epidermal cells, with an irregular layer of 3-5 guide cells, sometimes clearly defined, sometimes just appearing as 2-3 isolated ventral-central enlarged cells within a small group of dorsal stereids, guide cells becoming more clear in the distal and in the subulate part of leaves, where two layers of stereids often appear below and above guide cells; upper laminal cells quadrate to 
short-rectangular to rhomboidal; median laminal cells irregularly rectangular to narrow rhomboidal; basal cells narrow rectangular, hyaline, with straight and narrow walls; alar cells absent. Dioicous. Outer perichaetial leaves long subulate, inner perichaetial leaves oblong, abruptly acuminate and ended in a short point. Seta 5.0-8.0 mm long, light brown to orange, straight, slightly dextrorse at the base, vaginula narrow, 700-800 $\mu \mathrm{m}$ long. Capsules ovate-oblong, symmetric, $1.8 \mathrm{~mm}$ long, with 1(-2) row of phaneroporous stomata forming a ring at the base of the urn, exothecial cells quadrate to rectangular, up to 3:1, some irregular in shape, with narrow and straight walls; annulus not revoluble, formed by 4-6 rows of much smaller cells, oblate, reddish; columella persistent, up to $1.4 \mathrm{~mm}$ long. Opercula long-rostrate from a conic base, 1.6-1.7 mm long, rostrum slightly oblique. Peristome teeth up to $500 \mu \mathrm{m}$ long, deeply divided to near the base, more often to half the length of the teeth, evenly distributed along the rim, or grouped in pairs separated by an empty space as wide as one single tooth, smooth at base (seldom vertically or horizontally striated at base), becoming obliquely striated at the distal portions, sometimes appearing papillose due to these thick strations, attached to capsule 3-4 cells below the mouth. Spores spherical to somewhat irregular in shape, yellow-pellucid, smooth, 18-24 $\mu \mathrm{m}$ in diameter. Caliptrae cucullate, smooth, yellowish.

Studied specimens. URUGUAY. Tacuarembó, Gruta de los Cuervos, $31^{\circ} 17^{\prime} 0.7^{\prime \prime} \mathrm{S}, 56^{\circ} 02^{\prime} 30.3^{\prime \prime} \mathrm{W}, 220 \mathrm{~m}, 28 /$ II/2012, Suárez, Dematteis, Meza \& Vega 1372 (CONC, CTES, LIL). ARGENTINA. Rio Negro, Cascada los Alerces, 22/XII/1965, C. Matteri \& Barthe 14062 (CONC, LIL). CHILE. Provincia de Petorca, Zapallar, quebrada Cerco Largo, cerca del Portezuelo, 320 m, 19/XI/1981, Moreno 13850 p.p. (MO). Provincia de Marga-Marga, Los Perales de Marga-Marga, IX/1919, Jaffuel 055 (CONC); Lac Moeris, I/1918, Costes s.n. (PC, PUCV). Provincia de Cordillera, Cajon del Maipo, Quebrada el Canelo, 17/IV/1979, Mahú 12459 (MO). Provincia de Melipilla, Reserva Nacional Roblería del Cobre de Loncha, sendero Perales de Choy, 3409'01" S, 7058'37” W, 670 m, 24/IX/2007, Larraín $30042 \mathrm{~A}$ (CONC). Provincia de Talca, Vilches Bajo, 3553'S, 71²13'W, 350 m, 9/XII/1990, Mahú \& Tapia 50192

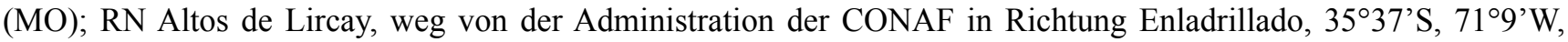

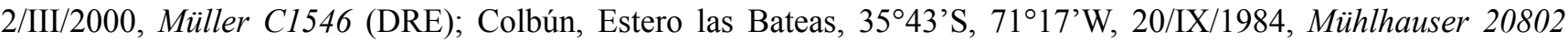
p.p. (MO). Provincia de Linares, Río Achibueno, sendero entre Retén Viejo y Las Mulas, $36^{\circ} 07^{\prime} 16^{\prime \prime} \mathrm{S}, 71^{\circ} 13^{\prime} 25.3^{\prime \prime}$ W, 740 m, 7/V/2016, Larraín 39513A (CONC). Provincia de Ñuble, Renegado River, 3654'S, 71'32’'W, 1200 m, 14-XII-2002, Ireland \& Bellolio 35926 (CONC); San Fabián, 8-II-1973, Mahú 13616 (MO, CONC). Provincia de Concepción, Road from Dichato to Burca, $3 \mathrm{~km} \mathrm{~N}$ of Dichato, $36^{\circ} 31^{\prime} \mathrm{S}, 72^{\circ} 54^{\prime} \mathrm{W}, 89 \mathrm{~m}, 7 / \mathrm{X} / 2001$, Ireland \& Bellolio 32222 (CONC). Provincia de Bío-Bío, El Saltuco on Queuco River $15 \mathrm{~km} \mathrm{~N}$ of Ralco, 3747'S, 71³2'W, $530 \mathrm{~m}$,

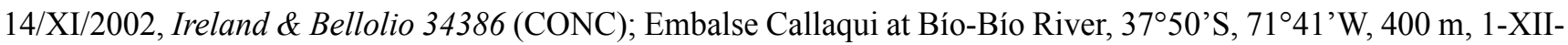
2002, Ireland \& Bellolio 35489 (CONC). Provincia de Malleco, Angol, Campo 14 pp (PUCV). Provincia de Cautín, Chile australis, ad Colico in rupibus, 15/XI/1896, Dusén 266 (LIL, LPS), Dusén 328 (PUCV); Pucón, en bosque virgen sobre tierra, 7-II-1935, Hosseus 256 (CONC). Provincia de Valdivia, Corral, en el suelo del fuerte, $39^{\circ} 52^{\prime} \mathrm{S}, 7^{\circ} 26^{\prime} \mathrm{W}$,

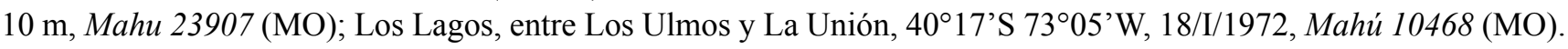

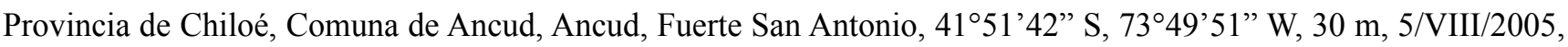
Larraín 25187 (CONC); Comuna de Castro, Castro, 18-I-1967, Montero 7850 (CONC); Castro, camino al museo de arte moderno, saliendo de población Triviño, 42 ${ }^{\circ} 7^{\prime} 47.9^{\prime \prime}$ S, 7347’34.9” W, 200 m, 1-II-2003, Larraín 23471 (CONC). Chili austral, Gay s.n. (PC 146666, lectotype, LIL, isotype, PC 701034). Chile, Prov. Central., in humides, Gay s.n. (PC 701035).

\section{Observations}

Aongstroemia gayana was found during extensive botanical explorations in Uruguay. The new records of A. gayana are the first report for this genus and species from the country (Fig. 2) in the "Gruta de los Cuervos", located ca. 14 kilometers NW from the city of Tacuarembó, and include a series of gorges surrounded by native forest. The species was found growing in stony grasslands, next to a water course, at $200 \mathrm{~m}$ above sea level. The herbarium material collected in Argentina by Matteri is from Cascada de los Alerces in Nahuel Huapi National Park, with Austrocedrus chilensis (D. Don in Lambert 1832:128) Pic. Serm. \& Bizzarri (1978:482) and Nothofagus dombeyi (Mirb. 1827:467) Oerst. (1871:354) woodlands, typical of the mountain range area. In Chile the species grows at river banks, humid road banks, or humid soil in Valdivian rainforests, as well as in dry Mediterranean areas, where it is much more rare than in the humid south and it is restricted to irrigated soil banks. It has a continuous distribution in Chile from Petorca Province in Valparaíso Region to Chiloé Province in Los Lagos Region, although it is not a very common moss, especially in the north part of its distribution. There is a specimen (Schwabe $n^{\circ} 20 / h, J E$ ) reported from Puerto 
Magdalena, Aisén Province (Herzog 1954), but this voucher has not been studied by us, so we can not be sure if it belongs to Aongstroemia gayana or other close taxon.

The four species of Aongstroemia present in South America can be distinguished by sporophyte and gametophyte characters (see key below). Dicranella vaginata (Hook. 1816:3B) Cardot (1908:60) from the tropical Andes can be confused with A. gayana. The general aspect of the plants is quite different though at simple sight, with plants of $D$. vaginata being dark green to blackish, having long-flexuose subulate leaves when dry, with subulae patent to spreading when both dry and wet. On the other hand, A. gayana plants are yellowish-green, shiny, and has tightly adpressed leaves with rounded apex to short subulate (except the distal and the perichaetial leaves), giving the plants a strongly julaceous aspect, typical of the genus. However, some specimens of A. gayana have most distal leaves long subulate, but these subulae are erect-adpressed, contrasting with the patent to spreading flexuose subulae seen in Dicranella vaginata. However, when studied under the microscope, both taxa are difficult to separate, with leaf areolation, costa anatomy, and sporophytic characters almost identical. In a recent contribution, Larraín et al. (2010) suggested that the main difference between $A$. gayana and $D$. vaginata would be the denticulation of the leaf subula and the abruptly contracted leaf apices seen in A. gayana. But after studying many specimens from different regions, including the types of both names, we have seen that both these characters are quite variable, and thus not useful for separating these taxa.

From the few fertile specimens we have studied, we can provisionally state that the main difference between both taxa would be the length of the peristome teeth, and the shape of the urn in the dry state. Aongstroemia gayana has erect, symmetric oval-oblong capsules, not strumate, with a slightly differentiated annulus, and the teeth are usually longer than $400 \mu \mathrm{m}$. Typical Dicranella vaginata has capsules either arched or inclined, often conspicuously strumose at base, with a conspicuous annulus, and the peristome teeth are generally shorter than $300 \mu \mathrm{m}$ [Observations based on the following specimens: COLOMBIA. In convallibus Andinum Granatensium alt. 1200-1500 hexap. Leg. Humboldt \& Bonpland, Herb. Bridel (JE 4009786, isotype); Nariño, Pasto, Ramirez-Padilla 5370 (MO), 5351 (MO), 3099-A (MO), Churchill \& Arbeláez 15965 (MO); Antioquía, La Unión, Churchill \& Sastre de Jesús 12876 (MO), Churchill 15392 (MO); Quindío, Churchill 17186 (MO); Valle del Cauca, Darién, Churchill 19534 (MO); Cauca, Volcán Puracé, Cleef \& Fernández-Pérez 557 (MO). ECUADOR. Azuay, Gualaceo, Buck 39169 (MO); Morona-Santiago, Løjtnant \& Molau 14624 (MO). PERU. San Martín, Rioja, van der Werff et al. 15779 (MO). CHILE. Provincia de Bío-Bío, $46 \mathrm{~km} \mathrm{~S}$ of El Barco Lake, 38 $8^{\circ} 1^{\prime} \mathrm{S}, 7^{\circ} 21^{\prime} \mathrm{W}, 900 \mathrm{~m}, 13 / \mathrm{XI} / 2002$, Ireland \& Bellolio 34322 (CONC); Provincia de Arauco, $15 \mathrm{~km}$ south of Tirúa, 6-XI-2001, Ireland \& Bellolio 33318 (CONC, MO); Provincia de Osorno, Termas de

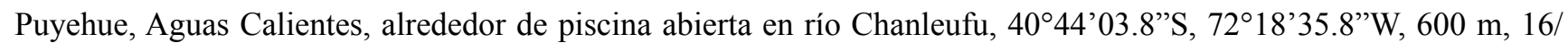
X/2005, Larraín 25392 (CONC); Provincia de Valdivia, La Aguada (Corral), sobre cancagua, a orillas del estero La Aguada, 22-II-1932, $30 \mathrm{~m}, H$. Gunckel 3176 (CONC); Provincia de Aisén, Sector Portales, por camino antiguo desde Lago Atravesado a Puerto Aisén, 45³8’42.8”S, 72²6’12.7’W, 283 m, 24/II/2017, Larraín 41567 (CONC).]

The other species of Aongstroemia present in Latin America have been already treated in several local floras (i.e. Allen 1994, Bartram 1949, Churchill \& Linares 1995, Crum 1994) and no further comments or illustrations are needed. The only novelty we found in our studies is the presence of A. filiformis in Chile. The specimen, collected in 1919, corresponds to the typical phenotype of the species, almost identical to the South African specimens illustrated in Magill (1981, Fig. 31:1-9), with ovate leaves that somehow differs with the mostly lanceolate leaves usually found in Neotropical specimens (cf. Crum 1994, Fig. 83:a-d).

A list of the studied specimens used to build the species key is given below. The key is adapted from previously published keys (Allen 1994, Crum 1994).

Aongstroemia filiformis: CHILE. Provincia de Bío-Bío, Contulmo, am See, 18/I/1919, K. Behn s.n. (CONC). COLOMBIA. Antioquía, Municipio La Estrella, Laguna en el Alto el Romeral, W de La Estrella, $6^{\circ} 08^{\prime} \mathrm{N}, 75^{\circ} 38^{\prime} \mathrm{W}$, 2070 m, 10/VIII/1992, Churchill 18536 (MO); Cauca, Coconuco, ca. 8 km E de Purace, 2²4'N, 76² 24'W, 3000 m, 11/I/1991, Churchill \& Rengifo 17265 (MO); Nariño, Pasto, entre Pasto y Buesaco, bosque de Daza, $1^{\circ} 12^{\prime}$ N, $77^{\circ} 16^{\prime} \mathrm{W}$, 2750 m, 28/VII/1998, Muñoz \& Churchill 98-345 (MO).

World distribution: Reunion (type locality), Madagascar, South Africa (Magill 1981), western Africa (O'Shea 2006), Central América (Allen 1994), Mexico, the Caribbean (Crum 1994), the tropical Andes and Chile.

Aongstroemia julacea: COLOMBIA. Distrito Especial, Usme, Páramo de Sumapaz, Parque Natural de Sumapaz, $4^{\circ} 17^{\prime} \mathrm{N}, 7^{\circ}{ }^{\circ} 12^{\prime} \mathrm{W}, 3700 \mathrm{~m}, 16 / \mathrm{VII} / 1998$, Churchill \& Muñoz 19307 (MO). PERU. Puno, Melgar, 7 km östl. des La Raya Passes, 4300 m, 5/V/1973, P. \& E. Hegewald 5502 (MO).

World distribution: Tropical Andes (type locality in Ecuador), Central America (Allen 1994), Mexico (Crum 1994), Brazil (Peralta 2015), East, South-East and Central Asia (Drugova 2010), West and South Africa, Madagascar (O’Shea 2006), Western Indian Ocean (Allen 1994). 
Aongstroemia orientalis: HONDURAS. Lempira, Montaña de Celaque, trail to \& summit of Cerro Mojón, 13 $\mathrm{km} \mathrm{SW}$ of Gracias, $14.32^{\circ} \mathrm{N}, 88.41^{\circ} \mathrm{W}, 2849 \mathrm{~m}, 17 / \mathrm{V} / 1992$, Allen 12292 (MO). MEXICO. Distrito Federal, $12 \mathrm{~km} \mathrm{~W}$ de San Miguel Ajusco, $19^{\circ} 13^{\prime} \mathrm{N}, 9^{\circ} 17^{\prime}$ W, 5/II/1986, Cárdenas 4412 (MO).

World distribution: South-East Asia [syntypes from Bhutan, Sikkim, and Burma (Myanmar)], also widely distributed in North, East, and Central Asia (Drugova 2010), Mexico (Crum 1994), Central America (Allen 1994) and Brazil (Peralta 2015).

\section{Key to the species of Aongstroemia from Latin America}

1. Plants more than $1 \mathrm{~cm}$ long, leaf costa percurrent to excurrent, perichaetial leaf costa long excurrent, leaf margins entire, capsules

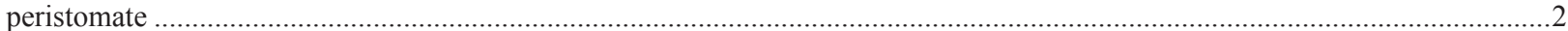

1'. Plants less than $1 \mathrm{~cm}$ long, leaf costa subpercurrent to percurrent, perichaetial leaf costa percurrent, leaf margins uneven to

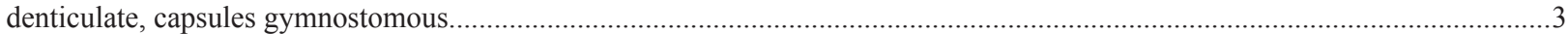

2. Perichaetial leaves subulae usually longer than the leaf length, upper leaf cells long vermicular, basal leaf cells short rectangular to quadrate ......

A. filiformis

2'. Perichaetial leaves subulae shorter than the leaf lenght (seldom reaching the same length as clasping base), upper leaf cells irregular in shape, quadrate to short-rectangular to rhomboidal, basal leaf cells long rectangular...................................... gayana

3. Leaves secund at the tips, apex widely-acute to obtuse to seldom rounded, margins crenulate to denticulate almost all around the

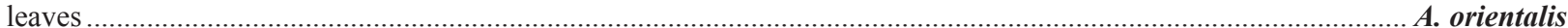

3'. Leaves straight, apex obtuse to rounded, margins with conspicuous teeth in the distal half, formed by the proyection of the walls of two adjacent cell. A. julacea

\section{Acknowlegements}

Thanks are owed to the curators of the herbaria cited for making specimens available for examination, and staff of CONC, JE, MO and PC for providing full access to collections and working space to JL. This research was sponsored by the Consejo Nacional de Investigaciones Científicas y Técnicas (CONICET), PICT (0810) and PIUNT (G631) from Argentina, and postdoctoral grant $\mathrm{n}^{\mathrm{o}} 3160556$ from CONICYT, Chile.

\section{Bibliography}

Allen, B. (1994) Moss Flora of Central America Part 1. Sphagnaceae-Calymperaceae. Monogr. Syst. Bot. Missouri Bot. Gard. 49: 1-242. Anderson, L.E. (1954) Hoyer's solution as a rapid permanent mounting medium for bryophytes. The Bryologist 57: $242-244$.

https://doi.org/10.1639/0007-2745(1954)57[242:HSAARP]2.0.CO;2

Bartram, E. (1949) Mosses of Guatemala. Fieldana, Botany 25: 1-442.

Bruch, P. \& Schimper, W.P. (1846) Brachyodus, Anodus, Seligeria, Blindia, Stylostegium, Hymenostomum, Weisia, Rhabdoweisia, Gymnostomum, Eucladium, Angstroemia, Arctoa, Cynodontium. In: Bruch, P., Schimper, W.P. \& Gümbel, T. (Eds.) Bryologia Europaea seu genera muscorum europaeorum, monographice illustrata, Fasc. 33-36. Schweizerbart, Stuttgart.

Cardot, J. (1908) La flore bryologique des terres Magellaniques, de la Géorgie du Sud et de l'Antarctide. Wissenschaftliche Ergebnisse der Schwedischen Südpolar-Expedition 1901-1903 unter leitung von Dr. Otto Nordenskjöld, 4 (8). Lithographisches Institut des Generalstabs, Stockholm.

Churchill, S.P. \& Linares, E.L. (1995) Prodromus bryologiae novo-granatensis: introducción a la flora de musgos de Colombia. Biblioteca Joseì Jeroìnimo Triana, no. 12.

Crum, H. (1994) Aongstroemia. In: Sharp, A., Crum, H. \& Eckel, P.M. (Eds.) The moss flora of Mexico, vol. 1. The New York Botanical Garden, Bronx, New York, pp. 116-118.

Drugova, T.P. (2010) The genus Aongstroemia (Dicranaceae, Bryophyta) in Russia. Arctoa 19: 247-252.

Eckel, P.M. (2007) Aongstroemia. In: Flora of North America Editorial Comittee (Eds.) Flora of North America, Vol. 27, Bryophyte: Mosses, part 1. Oxford University Press, New York - Oxford, pp. 360-362.

Gay, C. (1850) Atlas de la historia fisica y politica de Chile. Flora. Imprenta de E. Thunot y $\mathrm{C}^{\mathrm{o}}$, Paris

Gradstein, S.R., Churchill, S.P. \& Salazar Allen, N. (2001) Guide to the bryophytes of tropical America. Memoirs of the New York Botanical Garden 86: i-viii, 1-577.

Hooker, W.J. (1816) Plantae Cryptogamicae, quas in plaga orbis novi aequinoctiali collegerunt Alexander de Humboldt et Amat. Bonpland. Londini, Venbundt apud J. Harding.

Hooker, W.J. (1818) Musci Exotici, containing figures and descriptions of new or little known foreign mosses and other cryptogamic subjects, vol. 1. Richard and Arthur Taylor, Shoe Lane. London. 
https://doi.org/10.5962/bhl.title.10721

Jaeger, A. (1872) Adumbratio flore muscorum totius orbis terrarum. Part 2. Bericht über die Thätigkeit der St. Gallischen Naturwissenschaftlichen Gesellschaft 1870-71: 357-451.

Lambert, A.B. (1832) A description of the genus Pinus, with directions relative to the cultivation, and remarks on the uses of the several species: also descriptions of many other new species of the family of Coniferae. Messrs. Weddell, Prospect Row, Walworth. London.

Larraín, J., Suárez, G., Bednarek-Ochyra, H. \& Ochyra, R. (2010) The rediscovery of Dicranella circinata (Dicranellaceae, Bryophyta), with comments on other southern South American species of Dicranella. Nova Hedwigia 91: 361-376. https://doi.org/10.1127/0029-5035/2010/0091-0361

Magill, R.E. (1981 [1982]) Flora of Southern Africa, Bryophyta. Part 1, Mosses. Fascicle 1. Sphagnaceae to Grimmiaceae. Botanical Research Institute, Pretoria.

Matteri, C.M. (2003) Los musgos (Bryophyta) de Argentina. Bryophyte Diversity and Evolution 24: 33-100. https://doi.org/10.11646/bde.24.1.8

Matteri, C.M. (2004) The Mosses (Bryophyta) of Uruguay, their synonymy and distribution. Cryptogamie Bryologie 25: $147-167$.

Mirb. (1827) Kongelige Danske videnskabernes Selskabs Skrifter, Naturvidenskabeli Mathematisk Afdeling 9: 354. [1871]

Mitten, W. (1869) Musci Austro-Americani. Enumeratio muscorum omnium Austro-Americanum auctori hucusque cognitorum. Journal of the Linnean Society, Botany 12: 1-659.

https://doi.org/10.1111/j.1095-8339.1871.tb00633.x

Mitten, W. (1891) On the species of Musci and Hepaticae recorded from Japan. Transactions of the Linnean Society of London 2nd series: Botany, 3: 153-206. https://doi.org/10.1111/j.1095-8339.1891.tb00626.x

Montagne, C. (1845) Cinquième centurie de plantes cellulaires exotiques nouvelles. Décades I a VI. Annales des Sciences Naturelles, Botanique Sér. 3, 4: 86-123.

https://doi.org/10.5962/bhl.title.6485

Müller, C. (1848 [1849]) Synopsis Muscorum Frondosorum omnium hucusque Cognitorum. Pars Prima. Musci vegetationis acrocarpicae. Sumptibus alb. Foerstener. Berolini.

https://doi.org/10.5962/bhl.title.31

Müller, C. (1858) Addimenta nova ad Synopsin muscorum. Botanische Zeitung (Berlin) 16: 161-165.

Müller, C. (1859) Supplementum novum ad Synopsin muscorum. Botanische Zeitung (Berlin) 17: 214-215.

Müller, F. (2009) An updated checklist of the mosses of Chile. Archive for Bryology 58: 1-124.

O'Shea, B.J. (2006) Checklist of the mosses of sub-Saharan Africa (version 5, 12/06). Tropical Bryology Research Reports 6: 1-252.

Øersted, A.S. (1871) Bidrag til Kundskab om Egefamilien I Nutid og Fortid. Kongelige Danske videnskabernes Selskabs Skrifter, Naturvidenskabeli Mathematisk Afdeling 9: 331-538.

https://doi.org/10.5962/bhl.title.15275

Palisot de Beauvois, A.M.F.J. (1805) Prodrome des cinquième et sixième familles de l'Aethéogamie. Les mousses. Les lycopodes. De l'imprimerie de Fournier Fils. Paris.

Peralta, D.F. (2015) Dicranaceae. In: Lista de Espécies da Flora do Brasil. Jardim Botânico do Rio de Janeiro. Available from: http:// floradobrasil.jbrj.gov.br/jabot/floradobrasil/FB96135 (accessed 11 June 2019)

Pichi Sermolli, E.G. \& Bizzarri, M.P. (1978) The botanical collections (Pteridophyta and Spermatophyta) of the AMF Mares - G.R.S.T.S. Expedition to Patagonia, Tierra del Fuego and Antarctica. Webbia 32: 455-534. https://doi.org/10.1080/00837792.1978.10670102

Sommerfelt, C. (1826) Supplementum Florae Lapponicae. Christianae, Typis Borgianis et Gröndahlianis.

Wijk, R. van der \& Margadant, W.D. (1960) New combinations in mosses IV. Taxon 9: 50-52.

https://doi.org/10.2307/1217838 